\title{
The Works of Marc Chagall in Polish Poetry (from the 1950 s to the 1980s)
}

It must be said that a substantial number of Polish authors in the period considered here turned their attention to Marc Chagall's paintings and created some important lyrical texts. The prepotent inspiration gained by several Polish post-war poets from Chagall's art might be quite easily explained by a few factors. The most general one, the importance of which is not limited to the realm of the local (here: Polish) sensibilities, is the painter's characteristic visual language, close to fairy tale and myth and therefore very inspiring for the poets, regardless of the tradition they belong to. Indeed, it seems that Chagall's paintings, sometimes referred to metaphorically as "poetry" (in this context understood as a dream, fantasy and a certain kind of beauty unrelated to the experience of reality) have a quality to which the poets are secretly attached and which makes it an ideal subject for poetical interplays. The second one is certainly Chagall's biography and life-long interest in places and people filling his childhood spent in Vitebsk - a variety of subjects meaningful for writers coming from the same part of the world, also (or maybe: especially) in completely different historical circumstances. Thirdly, the painter's popularity among the Polish poets was stimulated by a dramatical historical context for interpreting his works, a context especially important in Central Europe, which was a scene for tragic historical events.

1 Chagall was also a poet himself, although none of his poetical works gained the same level of popularity as his paintings. 
At least two of these arguments seem, at the very best, two-edged and rather questionable after some reflection: the biographical tracks, including the interest in the shtetl as an artistic subject and in the decisive historical turn for the fate of the Central European Jewish community; none of these factors is very helpful for a poet undertaking a "face to face" encounter with a work of art and wishing to explore its unique artistic qualities. Rather, it seems poetry was to tackle a definitively nonartistic sphere of this historical period, its grief, and mourning, and to undertake the uneasy task of self-diagnosis in front of a painting created by a Central European Jew, an emigrant and a refugee. That is why a reflection on Chagall's presence in Polish poetry from the $1950 \mathrm{~s}$ to the 1980 os suits very well the general subject of this issue: the distinguishing qualities of a Central-European reading of works of art could not be observed more clearly, it seems, than on the material which I am going to analize. To make my argument more evident, I am going to juxtapose their poetic reflection with the place Chagall occupied in French poetry, which will further widen the panorama and allow me to remark on the "Polish" (i.e. apparently "Central-European" in this context) way of looking at Chagall's paintings (different from the "Western" one).

\section{A Belated Introduction: Jerzy Ficowski's "Letter to Marc Chagall" or a Painter in the Shadow of the Shoah}

As far as I know, there is no trace of Chagall's art in Polish poetry in the interwar period. ${ }^{2}$ This accounts for the considerable difference between the Polish and the "Western" reception of Chagall's art. While the painter lived in France in the years 1910-1914, not only did he encounter the most important French avant-garde poets, such as Blaise Cendrars ${ }^{3}$ (Wullschlager 136-139) and Guillaume Apollinaire (to whom Chagall devoted his work Homage to Apollinaire from 1912),

2 David Lyle Jeffrey suggested that the interwar volume by Roman Brandstaetter, Jerusalem of Light and Darkness (Jerozolima światła i mroku, 1935), beared "some thematic resemblances" to Chagall's paintings of that time (D. L. Jeffrey 219 (footnote)). The expression "resemblence" seems suitable here since it would be hard to prove the existence of any intentional links between the poems and the paintings. What must be remembered is the Polish poets of the interwar period could only have had a chance to see Chagall's works abroad, and rather in the Western, Parisian or possibly also Berlin context, as the paintings left by the artist in the Soviet Union were hardly accessible then.

3 Chagall accepted several titles for his paintings proposed by Cendrars; Wullschlager suggested that apart from his wife Bella, no one has ever come closer to Chagall as an artist than Cenrdars has (Wullschlager 139). 
but also-to a great extent thanks to the latter-gained recognition and fame in the Parisian artistic scene. He also became, along with his paintings, a hero of their lyrical works (vide Cendrar's poems Portrait and Atelier Chagall from 1914 and Apollinaire's poems Rotsoge from 1912, and $\grave{A}$ travers l'Europe (Through Europe) from 1914), referred to as an important artist of modern painterly trends, characteristically utilizing the distinctive features of a shtetl, and-to use Apollinaire's words - an artist with "a tormented soul” (Wullschlager, 164). In his autobiography, Chagall recounts an anecdote that Apollinaire, visiting his atelier in Paris, used the word "surnaturel" to describe his paintings, which in turn was to give a name to an era as "surrealism." Indeed, Chagall was seen by many contemporaries as an ancestor of surrealism (Wullschlager 164), an opinion from which the painter distanced himself. This point of view (namely, Chagall as a recognized artist of modernity) has never become a departure point for Polish poetry, whose serious encounter with the painter from Vitebsk began only after the Second World War, thus, in the shadow of the Shoah.

As Jerzy Ficowski reported, his poem "Letter to Marc Chagall" ("List do Marc Chagalla") came into being as an interaction between three very different elements: Chagall's art, a memory of the German anihilation of the Polish Jews and the authentic letters of children survivors of the Shoah. About the painterly component of this trio, Ficowski wrote:

Looking at reproductions of Chagall's paintings on and on again made me a great enthusiast of Chagall's fairy tales. Such works as Green Violinist, The Red Cock, Time is a River without Banks, Daughter in a window entered the poem, descended into an inhuman time, associating themselves with the ashes in the crematoria. (Cisowska 10, translation mine. Cf: Czyżewski 461-463)

"Letter to Marc Chagall" was written in 1956 and printed one year later in the volume My four cardinal points (Moje strony świata, 1957); in 1961 the text was used as lyrics to a cantata composed by Stanisław Wiechowicz (Cisowska). The date of the edition is not accidental, as the publication was possible only after the so-called Polish thaw in 1956, ending Stalinism in Poland and, among other profound social changes, bringing about a liberalization of cultural life. Both main subjects of the poem (the fate of the Polish Jewry and the paintings of Marc Chagall), mostly inconvenient in the years preceding the thaw, could then be undertaken and thoroughly elaborated.

In his poem, Ficowski quotes the authentic accounts of children survivors. The reader gets acquainted with the stories of Róża Gold and Frycek, who spent 
the war in hiding places, collecting dramatic memories of the tragic events they witnessed. The quotations from the documents are preceded by a poetical introduction of both children, built in a similar way:

What a pity that you don't know Róża Gold,

The saddest golden rose.

She was just seven when this war came to the end.

I've never seen her,

However, she's always looking at me.

Her six-year-old eyes

Were dying two thousand times.

What pity you don't know Frycek!

He was born just before the war.

And he wanted to be a herring, which has his own salt,

Or a fly, which was free to buzz.

Because he was allowed to be only a little.

[translation mine] (Ficowski 196-197)

Jaka szkoda, że pan nie zna Róży Gold, najsmutniejszej złotej róży.

Ona miała tylko siedem lat, kiedy skończyła się ta wojna.

Nie widziałem jej nigdy,

ale ona oczu ze mnie nie spuszcza.

dwa tysiące razy umierały

sześcioletnie oczy Róży Gold.

Jaka szkoda, że pan nie zna Frycka!

Jego matka zdążyła urodzić go tuż-tuż przed wojną.

A on chciał być śledziem, który ma swoją sól,

albo muchą, której wolno było brzęczęć.

Bo jemu wolno było tylko trochę być.

After the prosaic sections, i.e., transcripts of the accounts by children rescued from the Holocaust, recounting the true stories of Róża and Frycek, motifs derived from Chagall's paintings appear in the poem. The letter's addressee is 
turned to once again, this time, however, very differently, which suggests that the Shoah constituted a definite borderline, "before" and "after" which the painter's works cannot be interpreted in the same way:

What a good thing, Sir, you do not know Róża Gold!

The bunch of lilacs where the lovers lie would blow up in smoke.

The green musician's fiddle would cut his throat.

The gates of the Jewish cemetery would turn to dust or be overgrown [with brick.

Paint would char the canvasses.

What a good thing, Sir, you do not know Frycek,

Who sat behind the wardrobe and pretended that he was

[a spiderweb!

A daughter sits in a green window.

A samovar from Vitebsk whirrs throughout the years.

Sleepy kerosene lamps reek.

A winged herring blesses the fairs from heaven.

[translation mine] (Ficowski 196-197)

Jak to dobrze, że pan nie zna Róży Gold!

Wybuchłaby dymem kiść bzu, w której leżą zakochani.

Skrzypce zielonego muzykanta poderżnęłyby mu gardło.

Brama kirkutu obróciłaby się w proch albo zarosła cegłą.

Farba zwęgliłaby płótna.

Jak to dobrze, że pan nie zna Frycka,

co udawał za szafą pajęczynę!

Siedzi córeczka w zielonym oknie.

Szumi przez lata samowar z Witebska.

Kopcą senne lampy naftowe.

Skrzydlaty śledź jarmarkom błogosławi z nieba.

United as the material of the poem, Chagall's paintings ${ }^{4}$ and the horrors of the Holocaust are constantly presented as two different worlds, parallel, never

4 "Chagall-like visional pictures" are characteristic for Ficowski's poems devoted to Jewish themes, such as “To Jerusalem” („Do Jeruszalaim”) (cf. Czwordon, 158-165), which I decided not to analyze here due to space limitations. Discussing them would probably 
meeting. In the beginning, the fact that Chagall did not know the children named in the poem is mentioned with regret; afterwards, it is mentioned with relief. Chagall's paintings - at least those recalled in the poem ${ }^{5}$ - know nothing about their dramatic experiences and about the evil of the times of the war, ${ }^{6}$ and this is considered, in the end, a positive thing. The Holocaust cannot be expressed by any human word" - nor by any painting (as we read in "Letter to Marc Chagall": "lots of bones [buried deep the the ground] which wish very much that we keep silent about them"). At first, as mentioned above, the poem suggests that "it's a pity" that Chagall, painting the works recalled by Ficowski, did not know the children Holocaust survivors and their fate, as if hoping for a painterly commemoration of their suffering. Then, however, gratitude is expressed for the fact that Chagall's paintings could stay intact despite the horrors of the times, preserving a world which no longer exists. Therefore, Chagall's paintings, Ficowski suggests, not only have a precious quality of saving the annihilated world of shtetl, but also are able to overcome the tragic fate of millions of victims:

I think that they [Róża and Frycek] will find a shelter

And that I will meet them

In the safe nooks

Of the fortune-telling colours

of yours, mister Chagall.

[translation mine] (Ficowski 199)

lead to very similar conclusions about the "use" of Chagall in Ficowski's poetry to the ones drawn at the end of this part of the article.

5 Sometimes, only a motif from a painting is invoked, which makes it difficult to state which of Chagall's works Ficowski had in mind. Probably, the paintings which inspired him were (in the order they appear in the poem): The Lovers in the Lilacs (1931), The Green Violinist (1923-1924), Gate to the Cementary (1917), Ida at the Window (1924), Time is a River without Banks (1930-1939). Several motifs that are named in the poem appear in many paintings (such as a samovar, kerosene lamps, a winged herring, a cock).

6 Of course, there are numerous works by Chagall, which are thematically connected with the Second World War and the persecution of European Jews, e.g. White Crucifixtion (1938) and Martyrdom (1940). By not referring to them in his poem, Ficowski makes a meaningful gesture, which clears the way for his reasoning.

7 This observation repeated by many, from Adorno to Różewicz, was expressed also by Ficowski: "There are no responsible, mature words which would stand the weight of this crime and tragedy" [translation mine] (Cisowska 10). 
Myślę, że znajdą przytułek

i że spotkam ich [Różę i Frycka] jeszcze

w bezpiecznych zakamarkach

wróżebnych kolorów

u pana, panie Chagall.

In his article about the "Letter to Marc Chagall", Ficowski referred to Chagall's paintings as a "fairytale." I suppose that the reason for this cannot be reduced to the colourful and magical atmosphere of many Chagall's paintings (creating such "fairytales" after the war, which Chagall actually did, would then be an act of sugarcoating the dramatical reality, a thing that Ficowski would probably not be fond of); rather, it seems, it it due to the fact that those works, just like fairytales, have the ability to convey a message that resists the passage of time. What kind of message could it be, then?

To search for the answer, let us return to the central part of the poem. In a highly poetic and metaphorical language, it conjures an image of new deserts, created where life once flourished, over the ashes of victims of the Nazi concentration camps: the exceptional deserts created in a way they have never come into being before. Ficowski writes:

Me, a man, me, a son of this soil,

Me, a not burnt brother of their

I still see how your cock, who has lost its sight,

Protects the scraps of human affairs

And on the last day of the destruction

hovers over the ashes.

[translation mine] (Ficowski 198-199)

Ja-człowiek, ja-syn tej ziemi,

ja-niespalony ich brat

jeszcze widzę, jak pana kogut oślepły

chroni ogryzki ludzkich spraw

i w ostatnim dniu zniszczenia

unosi się nad popiołami.

The cock, a bird present in many of Chagall's paintings, plays a significant role here. Its flight over the deserts of human ashes "on the last day of destruction" resembles at least two Biblical scenes and therefore deserves an explanation that extends beyond its meaning in the painting. Ficowski alludes both to the 
biblical story of God's creation of the world ("In the beginning ... the earth was without form and void ... and the Spirit of God was hovering over the face of the waters" (Genesis 1, 1-2)) and to the story of the flood ("After forty days Noah ... sent out a dove to see if the water had receded from the ground.... When the dove returned to him in the evening, there in its beak was a freshly plucked olive leaf! Then Noah knew that the water had receded from the earth" (Genesis 8, 6-11)). The poet makes Chagall's cock a symbol of what remains alive after a catastrophy: like a dove over the waves of the flood when the waters started to subside, the cock is floating over the desert of ashes in "the last day of destruction," signifying therefore the end of mouring and hope for the future after a long time of massacres and fear. The first parallel is of a different kind: as the Spirit of God was hovering over the waters when the divine act of creation began, so is Chagall's cock hovering over the desert created by men violating all the moral rules and contradicting the works of God. It is therefore a weak sign of something in-place-of-the-divine, substantially different from the evil which turned the Earth into a desert, much more terryfying than the "void" of the first day of creation, resulting from the cruel acts of humanity itself. Against the unimaginable horror, which turned millions of people into ashes, the cock, which has lost its sight (perhaps after witnessing what was too painful to observe), seems to be something very small and unimportant. It is still, Ficowski suggests, a sign of hope not so much for changing the past and raising the murdered from the dead (after all, the drowned never came back to life after the biblical flood), but for the end of catastrophy and a chance for revival, built upon the fact that "the scraps of human affairs" still exist in very few places, but among those, on Marc Chagall's canvas. In Ficowski's poem, the existence of these paintings means that there is a sphere of art impervious to all the evil on Earth, although it is unable to prevent its incarnation either. Chagall's paintings show that what seems weak can withstand the powerful, that beauty can survive atrocity, and a superior order and harmony, also of a religious and spiritual nature, can withstand evil. Ficowski would probably agree with Raïssa Maritain, who noticed that whenever Chagall portrays what is painful, he completes it with a consolation: "Chagall's world staggers under compassion" (Maritain 40). Due to this very quality, Chagall's paintings can be looked at after the Holocaust without the feeling of looking at something improper.

Even if not directly influenced by each other, poets work in the shadow of their literary ancestors. This obvious truth is even clearer when we turn to the poems written by Polish authors grouped together around Chagall's works. Among these, Ficowski's "Letter to Marc Chagall" was a milestone and, even if not directly referred to, it is nonetheless present in works of other poets. None 
of the poets repeated Ficowski's achievement of creating a work of such overwhelming power gained by juxtaposing documents of the time of the Shoah and reflections on the paintings recording the forever-gone world of the shtetl. From that point, which is exactly from the beginning of its appearance in Polish poetry, Chagall's works are bound with the subject of the Central-European state of mind: the consciousness of people living on this place on Earth, where the Jewish minority had lived for centuries and where it experienced the cruelest events of their tragic history.

There is, however, one more important thing about "Letter to Marc Chagall". Ficowski cleared the way for interpreting Chagall's shtetl not just as a place to be praised and commemorated, a place where people lived in joy and love in the (rather distant) past, but also a semi-mythical place of hapiness, where the vital sources of life, such as love, grace and harmony, remain untroubled. If the importance of Chagall's paintings resided in the memory they evoke, they would not have the power to heal the wounds and grant an asylum after the horrors of the war; on the contrary, perhaps, by remembering what has definitely disappeared, they would contribute to the overwhealming pain over the terrible loss. They would not be able to withstand the evil of the historical events either. Their meaning, according to Ficowski (who was soon to be followed by others) lies in their ability to preserve and at the same time transcend the beauties and joys of the shtetl reality, as if they were built upon something greater than the individual life of men and animals; an ability to make the viewer believe that the visible world is something good-also in a serious moral sense. Chagall's art, rooted in the Jewish spiritual and cultural tradition which granted humanity the amazing and visionary book of the Bible, is therefore, Ficowski persuades us, stronger than the dark powers of history, and if the horror of the Second World War is ever to be overcome, it must be done with the help of Chagall, his heritage and the beliefs which it silently but steadfastly proclaims.

In this context in might be worth mentioning that Chagall got acquainted with the "Letter to Marc Chagall" in 1960, when Ficowski sent him a French translation of his poem (Sterna-Wachowiak 11). Still earlier, already in 1959, he received the Polish original sent to him by his friend, a journalist Dawid Lazer, but the painter was not able to understand the text written in Polish (Kossewska 55). After some years, the painter created graphical works illustrating "Letter to Marc Chagall", and they were edited together with the poem in France (1969) and in Poland (1988). Importantly, the difference between the paintings which inspired Ficowski and the aquaforts illustrating the poem is evident. The artist re-used motifs from his own works, which Ficowski alluded to; however, he reinterpreted them: no deeper relations of a supranatural kind 
exist between various elements of the painting anymore, no secret harmony between things and people, "as if the binds were broken" (Sterna Wachowiak 11; cf. Kossewska 40).

\section{Joanna Kulmowa Chagall, or Catastrophic Idyll}

In her poem entitled simply "Chagall" (written in $1958^{8}$ and published in her volume God's dying (Boże umieranie) in 1962), Joanna Kulmowa gives a loose ekphrasis of the painting entitled Three Candles (painted between 1938 and 1940). ${ }^{9}$ A picturesque scene of the shtetl, with the trappings typical for Chagall (lovers, angels, donkey, etc.) is different from similar ones painted in the proceeding decades, and Kulmowa seems to notice the difference:
A fiancée, a fiancée,
Look, a little donkey is neighing on a meadow.
I won't go there, where there are three candles,
And three falling angels.

Let's not wait, not even a little while,

The heaven is plaiting wreaths of rain.

It is sultry here, so many butterflies.

Are you still alive? Yes, I am.

A fiancée, a fiancée,

A dead Hershel is playing for me.

Sometimes it's scary in this little town.

Are you still alive? Yes, I am.

Come to the heaven. You'll rest there.

Just don't look. Just don't think.

We'll fly aslant,

And we will find ourselves nowhere.

[translation mine] (Kulmowa 59)

8 This exact date is given by Kulmowa herself in a collection of her poems Moja petnia czyli wiersze lubiane (Warszawa 2000: 59).

9 The poem is sometimes described — apparently by mistake-as referring to the work entitled Above the Town (1914-1918). Cf. Biała 112-115. 
Narzeczona narzeczona

patrz osiołek rży na łące.

Ja nie pójdę tam trzy świece

trzy anioły spadające.

Nie czekajmy ani chwili

niebo z deszczu wieńce wije.

Duszno tutaj od motyli.

Jeszcze żyjesz? Jeszcze żyję.

Narzeczony narzeczony

mnie przygrywa zmarły Herszel.

Straszno bywa w tym miasteczku.

Jeszcze żyjesz? Żyję jeszcze.

Chodź do nieba. Tam odpoczniesz.

Tylko nie patrz! Tylko nie myśl!

Polecimy skośnie, skośnie

aż się nigdzie nie znajdziemy.

Despite the title (which might suggest an intention to encompass the whole œuvre of the painter), the poem enables the reader to find easily the pictorial basis that inspired its creation. Chagall's painting The Three Candles has its characteristic features, all of which have found their equivalents in numerous elements of the poetical world, such as three candles, falling angels, a pair of lovers ("A fiancée" is feminin (narzeczona) in the first stanza and masculine (narzeczony) in the third one), a donkey, and the musicians. Most of all, Kulmowa preserved the essential quality of the painting's atmosphere, which is a mood of obscure anxiety, uneasiness or even fear of two lovers floating in the air and observing the scenes taking place below them. The natural joy of the couple about to be married (the white dress and the veil clearly signify a bride, thus also certain innocence or even simplicity) is replaced in the painting by a deep concern, visible on the young people's faces. The man embraces the woman as if to prevent her from looking at something he has already noticed; her position and the way she holds his hand suggest that she is very uncertain and looks for support and solace. Altogether, their flight seems to be an escape rather than an act of light-heartedness.

At first sight, nothing in the painting gives reason for such feelings. The composition of the painting (a green, tree-like shape on the top, small white clouds- 
or perhaps cloudlets of smoke from the candles), an open perspective of the landscape, and a rather serene palette suggest something rather opposite. Only after having noticed the uneasiness of the floating couple does the viewer realize that the red patch in the lower part of the picture plane is a cloud on which the couple is taken away from the earth by a gray angel, visible on the left. Both the angel and the couple seem to be looking at something beyond the picture plane, something that makes them anxious. This suggestion is strengthened by the behaviour of two figures visible in the lower part of the painting, a man and a woman, or perhaps two women, both pointing up to the floating couple; one of them is also looking in the same direction as the lovers and their guardian angel, as if wishing to denounce their way of escape. The red patch, together with the figures of the falling angel in the very centre of the picture plane, creates at the same time a vague, but important conotation of the flames of hell, which is the realm of the fallen angels-the depiction of evil in its most archetypical form. In short: "A presentiment of coming events hangs over the lovers in The Three Candles" (Erben 108).

When he painted this painting, Chagall lived with his family in France; in 1940, they moved from Paris to Gordes in Provence, to a place more distant from the German troops. Shortly before moving, they obtained French citizenship, which was important during the period of Nazi Germany's growth in power, which in the long run-and certainly after the outbrake of the Second World War-threatened the Jewish people also in the countries under attack. The painting could be interpreted as a scene presenting the growing, albeit slowly, danger awaiting the European Jewish community just before the catastrophy began; a moment when escape is still possible, but when real relief and light-heartedness can no longer be obtained. Kulmowa seems to allude to the fact that the painter and his beloved wife Bella (portraited in many of his works) were forced to escape from France and flee to America shortly after Chagall had painted The Three Candles-just like the couple in the picture is leaving the small town, frantically and anxiously.

Kulmowa's poem evokes a very similar emotion in its reader as the painting is prone to stir in its viewers. It also creates an atmosphere which is very close to the mood of the painting. The strange and deeply moving mixture of subtle beauty of countryside motifs present in the poem, almost idyllic ones (lovers, butterflies, sky, a little donkey) and the ones that awake restlessness and fear (a "sultry" and "scary" atmosphere of the little town, a dead man playing music, and most of all dialogical parts, a repeated question "Are you still alive?" and the words which should be attributed to the man embracing his fiancée: "Just don't look. Just don't think") correspond with Chagall's work outstandingly. 
Kulmowa is faithful to Chagall also in this way that she is not referring directly to the horror of the Shoah, which would be a dominant perspective after the Second World War (and exploited already by Ficowski), but not overtly present in the painting. Instead, the poem stresses certain elements of the painting and, therefore, especially in its final stanza, points the reader's attention to the situation of people who have no place on Earth to escape and who can be saved only by the heavens. Such a conclusion, by placing the floating couple somewhere between redemption and annihilation, presents Chagall as a painter of the end of the world as it is known by the pair of lovers, who, even if miraculously saved, have passed the point of no return, as they prefer "not to see, not to think" after the events they have witnessed and experienced. In the painting, there is still hope for the couple to be saved; in the poem the necessity of going "nowhere" in order to rest $\mathrm{t}^{10}$ seems to be a post-war perspective on what Chagall could have only had presentiments. ${ }^{11}$

\section{Tadeusz Śliwiak and Wojciech Młynarski: A Central-European Fiddler on the Roof or "That Is Not What Mr Chagall Painted"}

In 1964, the Broadway stage production entitled Fiddler on the Roof started its outstanding career, becoming one of the most popular musicals in history. ${ }^{12}$ The plot of the play is based on the story of Tevye, the Dairyman written by Sholem Aleichem, its title, however, refers to the works of Marc Chagall, especially to one of the panels he painted for the Jewish Theatre in Moscow (Chagall spent the years 1920-1922 in the capital of the Soviet Union and earned his

10 Another possible reading of this phrase - going nowehere and having a rest there-might be of a meta-artistic nature. Kulmowa stresses in her poem an interesting detail form the painting's composition, namely the fact that the couple is "flying aslant," and heading towards the corner of the painting, which means not only to run away from the dangers below, but also, so to say, out of the painting as such, away to a completely different world. This is a real "nowhere," a place one can have no idea about, existentially and essentially different from what one is used to. Such a radical difference, signalized by the movement of the couple visible on the picture, has its equivalent in the straightforward character of the last verse of the poem: "and we will find ourselves nowhere."

The volume God's Dying, in which the poem was published, contains quite a lot of poems which elaborate pictures and motfis common in literature dealing with war and the Shoah (cf. Stankowska 52-54); the way that Kulmowa looks at Chagall seems coherent with the context of the whole book. 
living there by creating paintings used on stage as parts of the scenography). The panel entitled Music depicted a shtetl fiddler wearing a green cup and a tallit, dancing on the roofs of two neighbouring houses. After leaving the Soviet Union, Chagall reconstructed this work in a widely-recognized painting The Green Violinist (1923-1924) (Wilson, 176).

Interestingly, the very same year when Fiddler on the Roof premiered on the stage, a poetical volume by Tadeusz Sliwiak entitled Resin (Źywica) was published, which contained a poem "The Green Violinist (a Free Translation from Chagall)" (“Zielony skrzypek [wolny przekład z Chagalla]”). The date of publication, the same as the date of the première of the American musical, might be (and probably is) a pure coincidence. ${ }^{13}$ However, the inspiration gained from The Green Violinist led both the libretto-writer and the poet on similar tracks. Let us turn to the poem.

\author{
“The Green Violinist (A Free Translation from Chagall)” \\ In Vitebsk there's frost \\ and glass roads \\ the crooked, frostbitten fingers \\ pray in an inn \\ by a gold orthodox chuch of a samovar \\ any moment an old Jew is comming here \\ the one with a green face \\ he will tilt his head \\ and play \\ so beaufifully \\ so shrilly \\ that in Vitebsk \\ the snow will stop in the air
}

13 Whether Śliwiak might have heard of the preparations for the American stage production is unclear. In the middle of the 1960s, the cultural news from the opposite political block were limited; Śliwiak still worked in the years 1960-1963 as a dramaturge in Teatr Rozmaitości in Cracow, and translated into Polish a few American plays: a drama based on Uncle Tom's Cabin by Harriet Beecher Stowe in 1961 and Orpheus Descending by Tennessee Williams in 1963 (just a few years after its Americam première), which makes his acquaintence with Fiddler on the Roof all the more probable. 
and up in the sky

white and red horses will be seen

in a wedding veil

long and reaching down to the ground.

[translation mine] (Śliwiak 47)

“Zielony skrzypek (wolny przekład z Chagalla)”

W Witebsku mróz

i szklane drogi

modlą się krzywe odmrożone palce

w karczmie

przed złotą cerkwią samowara

zaraz tu przyjdzie stary Żyd

z zieloną twarzą

przechyli głowę

i będzie grać

a tak ładnie

a tak cienko

że aż w całym Witebsku

śnieg się zatrzyma w powietrzu

i ukażą się na niebie

rude i białe konie

w długim aż do ziemi

weselnym welonie

In the poems analized earlier, the poetical image was dominated by the experience of the Shoah (Ficowski) and the intuition of the future horrors at the dawn of the Second World War (Kulmowa); none of these appears here, as if they have never occured-as if Sliwiak was willing to stay faithfull to the painting, created long before the Nazis came to power in Germany. Chagall's paintings, created in the 1910 s and 1920s, which often depict the shtetl with its colourful tradition and exotic setting (exotic, of course, from the West-European or American point of view; vide the observations by the French avant-garde poets), enable the viewer (also the one, either living in another place or in a very different time, who has never experienced the shtetl himself) to "envisage the 
richness of the communities, which the Jewish populace of Eastern Europe enjoyed ... before it was all lost." (Frankel 345-346).

A similar perspective is presented in a poem by Jan Winczakiewicz "From Chagall” (“Z Chagalla," 1955):

A bride in a white veil

floats quietly along the Milky Way.

Seven hundred stars burn in the sky

and seven hundred candles in a synagogue.

A groom follows his beloved one,

with a large bouquet in his hand.

The night is black. Sad rabbis

stroke their beards, equally black.

The whole ghetto is looking for lovers,

all Zacheriahs, Judiths, Sauls.

Only the old, blind women in their wigs

smile to them tenderly.

[translation mine] (Winczakiewicz 200-201)

\section{"Z Chagalla"}

Panna młoda w białym welonie

płynie cicho po mlecznej drodze.

Siedemset gwiazd na niebie płonie

i siedemset świec w synagodze.

Za wybraną pofrunął pan młody, w ręku trzyma bukiet olbrzymi.

Noc jest czarna, czarne są brody,

które głaszczą smutni rabini.

Zakochanych całe ghetto szuka,

Zachariasze, Juduty, Saule.

Tylko ślepe staruszki w perukach

uśmiechają się do nich najczulej. 
Thanks to Chagall's paintings, the poets found a way of describing the non-existing, and therefore open to idealization, Jewish world of Eastern Europe in the interwar period, living peacefully in a fairy-tale-like scenery, an image equaly pictoresque and oversimplified, qualities obvious to every reader.

However, how exactly should such a poetic gesture be described? Was its creation an effort of poets who try to talk about the paintings while remaining faithful to them, to the extent which makes them silence any remarks on what happened after the pictures were painted? Would this mean that they have more respect for the painting than for the historical experience? Is this a gesture of joy and affirmation of what there used to be, no matter what happened then, although this knowledge must be silently taken for granted? Would it be, then, a simplified (perhaps oversimplified) version of Ficowski's idea, deprived of Ficowski's deep compassion and mourning?

To get closer to poems like the one by Śliwiak, it must be remembered that in communist Poland the memory of interwar cultural diversity was for ideological reasons a subject of manupulation; this is also an important factor in understanding the value of a "simple description" which Śliwiak undertakes (Winczakiewicz's case is somehow different, as he never returned to Poland after the war from Western Europe). Affirmation of "The Green Violinist" means bringing back to memory the past which was not only destroyed physically by the Holocaust, but also lied about in the decades thereafter. Without saying a word about it, Sliwiak makes the reader think both of a world no longer there and the many different reasons for this state of affairs. No matter what the poet's intentions were, poems like the one by Sliwiak contributed, by making use of Chagall's iconography, to establishing a locus communis in Polish poetry, which was to be exploited thereafter, and the image of Chagall it was based upon was readily taken for granted.

The meaning of Chagall's paintings in Polish culture as a sign of a peaceful existence of the Jewish minority in Eastern Europe was well established when Wojciech Młynarski wrote the poem (used by him also as lyrics to a well-known song) "As Mister Changall Painted" ("Tak jak malował pan Chagall”). ${ }^{14}$ This descent of Chagall's works to the realm of popular culture was done in a way which proves the power of the artistic vision to become a part of social discourse.

14 Different information can be found regarding the date of creating this song. In the collection of Młynarski's poems the date below the text is 1981 and, as this is the date Młynarski himself suggested to be the correct one, I assume it is true. Other sources (recolections about the March 1968 and its aftermath) suggest it was written shortly after 1968. Different opinions are confronted and discussed in Karolina Szurek's "Jak malował Chagall." 
Młynarski’s poem starts with a slightly nostalgic (although not sentimental) image of a shtetl:

These small cities don't exist anymore, and the dust of forgetting has covered the streets, white cups, a swarm of merchants, a fence and a goat - feeder of a family, Shmul the tailor with a great beard, who could sew a wedding dress better than anyone. And the lover's eyes glitter a lilac mist covers the forgotten world which floats away, with one head of a cock and another on a white cloud [of a sheep just as mister Chagall painted.

[translation mine] (Młynarski 212)

Tych miasteczek nie ma już, pokrył niepamięci kurz te uliczki, lisie czapy, kupców rój, płotek z kozą żywicielką, krawca Szmula z brodą wielką, co jak nikt umiał szyć ślubny strój.

A zakochane oczy lśnią, otula się liliową mgłą zapomniany świat i płynie, płynie w dal, z kogucim i baranim łbem, na białej chmurze ginie, hen, tak jak malował pan Chagall.

In the third stanza, the main subject of the poem is introduced, and Chagall's painting reveals its importance as a fundamental point of reference for the Polish social imaginary:

These small cities don't exist anymore,

However, my friend had your eyes, my dear tailor, when the train whistled goodbye. 
On the platform,

our handshake was left

And whisper: "Keep well... write to me..."

And the crying eyes glitter,

The March mist covers the sad train

Which goes away,

A dream about a warm, good home

Perishes in a dark tunnel,

That is not how mister Chagall painted!

[translation mine] (Młynarski 213)

Tych miasteczek nie ma, nie,

ale, krawcze, oczy twe

miał kolega, gdy pociągu zagrzmiał gwizd,

pozosały na peronie

nasze zaciśnięte dłonie

i ten szept: „Bywaj zdrów... Napisz list...”.

A zapłakane oczy lśnią,

otula się marcową mgłą

smutny pogiąg i odpływa w dal, hen, w dal,

o ciepłym, dobrym domu sen

w tunelu czarnym ginie, hen,

nie tak malował pan Chagall!

Młynarski alludes here (clearly, albeit rather carefully, censorship in People Republic of Poland was not dormant in 1981) to March 1968, when a series of student and intellectual protests against the communist regime in Poland erupted. The crisis ended with security forces suppressing the student strikes and with the subsequent repression of the dissident movement; it resulted also in mass emigration, and an antisemitic campaign started by the Minister of Internal Affairs, which had to do with a power struggle within the Polish Communist Party. Consequently, at least 13,00o people of Jewish ancestry emigrated from Poland after having suffered from many forms of official harassment. All these events are described in the poem as, so to say, violating the joyful and harmonious spirit of Chagall's paintings, which-and this is an important moment-serves Młynarski as an unquestionable point of referrance during the discussions about the place of Jewry in the Polish society. When after the Second World War almost nothing was left which could help recall 
the centuries-long presence of the Jewish minority in Poland, Chagall's paintings, with their idealistic varnish, apparently became a supplementary witness and a token of remembrance for the poets ${ }^{15}$ (and allowed them to skip a too complicated and emotionally exhausting subject, i.e. the discussion about the actual relations of the two groups in Poland).

Młynarski's poem is interesting also from another point of view. It is more than clear that the meaning of the work of art changes with time (Berger 179). Sometimes, however (and this is an endlessly more interesting observation), in front of a painting we are forced "to situate ourselves in history" (Berger 180), to realize what is our own position and state of mind in the flow of external events. This happens in the second part of Młynarski's poem. The presence of the Jewish communities in Poland in the interwar period, brought to the poet's mind by Chagall's paintings, stirs remorse and disagreement on account of the political decisions made by the communist regime. Chagall's figures, which incarnate mysteriously in real people (the eyes of a friend, who is about to depart, resemble the eyes of Chagall's tailor), make one define himself in terms of political views; however, they also make one realize, that one's own reading of art is never free from historical experiences which have shaped one's biography. The way we "activate" the sense of a painting — in this case a painting by Chagall-is historically variable, and a reading of Chagall in the Polish context after 1968 brings about a different, and still sadder, reflection than it did before.

\section{Pasierb's "Chagall's 'Moses," or the Fairytale About the Magical Ethical Basis}

A poet and an art historian, Stanisław Pasierb, who was also a catholic priest, was greatly inspired by the fine arts (Peron 2015) and among his poems there are several which allude to the works of Chagall (some of these poems were written when Pasierb visited Jerusalem and the Holy Land). It is hard to say definitively which of Chagall's paintings or prints Pasierb had in mind while

15 This resembles another poetic-artistic liason which came into being around the same matter, i.e. the centuries-long Jewish presence in the Polish society and the radical end of this coexistence in March 1968. In 1971 Stanisław Grochowiak published a poem entitled "A Gate in the Old Town (a copy of painting by Aleksander Gierymski)" ("Brama na Starym Mieście (kopia obrazu Aleksandra Gierymskiego)"), in which, using a painting by Gierymski depicting the Jews living in the heart of nineteenth-century Warsaw, he deals with the dramatic events which took place in the same city in 1968 and its consequences (Dąbrowski 170-175). 
Pasierb points to the fact that the painting shows a scene different from the one described in the Bible, surprisingly adding that "perhaps it is better so." As it can be read in the Book of Exodus, Moses approached his compatriots with the Tablets of Law twice: for the first time, when carrying them down from the mountain, he found the Israelites worshiping a golden calf. In his anger, Moses smashed the stone tablets on the ground. After the punishment of the unfaithfull, Moses ascended the mountain again and returned to his people with another set of two tablets, on which the Ten Commandments, dictated by God, were written.

When returning for the first time, Moses destroyed the tablets, which in a way symbolized the broken convenant between God and the disobedient Israelites. In the poem, based on the painting, the tablets thrown on the ground do not break, but are lying "as on a building site," as if they formed a basis or a foundation, one might think. Such a redefinition undertaken by Pasierb of the Biblical scene painted by Chagall is very radical and openly against the meanings of the painting. The distortion of the Biblical meaning, however, clears the way for imagining, simply speaking, a better world, where evil has never come into being. This is a world where lovers can be happy together, untroubled, and no sinful disobedience occurs; the little donkey remains what he is, and no golden calf appears in the peaceful landscape. Without sin, there would be no evil and, consequently, no drama in the ever-growing vicious circle of threat-and-danger.

Described in this manner, the paintings of Chagall (the paintings, and not the painting, as the poem, although directly pointing in its title to one work only, seems to encompass in its diagnosis Chagall's work as a whole, by recalling motifs unseen in any of the compositions with Moses) reveal a very surprising quality. The attributes often ascribed to them, such as "fairytale" or "magical" atmosphere, are underlined but gain a sense much different to the one we are used to when discussing Chagall. The great painter, Pasierb would agree, bewitched the world. However, this was achieved, the poet suggests, not by showing lovers hanging in the sky or supernatural animals, but by giving the world a different foundation than that of the story of people regularly breaking the ethical rules imposed by the Absolute. Thus, instead of a broken covenant-Pasierb continues his explanation of the painting-there is a strong basis for the future generations. The idyllic atmosphere created by Chagall is rooted in something deeper than the colourful and slightly exotic realia of the shtetl and the Yiddish-speaking community. Not only do the motifs and the mood of a fairytale matter here, but their most important function, which is to help people to distinguish between good and evil, and to turn to the first one. 
Chagall is depicted by Pasierb as a magician, not a shoddy one, but one who knows the profound truths about the human world and nature. If we long for the world he painted, Pasierb suggests, this is not because of the picturesque layer of this art, its memorable shapes and colours, but because of the power of the traditional and religious world he depicted. That is why this art attracts viewers: it appeals to them by suggesting a profound order, which organizes the world of Chagall's shtetl, and is rendered through the bright colours of the painting.

This reading of Chagall as a painter sensitive to the problems of the ethical order gained from a religious tradition is a concept introduced to Polish poetry by Pasierb. Still, it has a counterpart in the French poetry, namely, in the poetical reflections undertaken by Raïssa Maritain. The poetess, wife of Jacques Maritain, was a Russian Jewess, who emigrated to France and converted to Catholicism. ${ }^{16}$ Sharing with Chagall a similar background and the experience of a shtetl, she was especially interested in these elements of his works which combined Jewishness and Christianity (Maritain) - a quality of his paintings noticed also by art historians (Frankel 346: Erben 50-52).

Juxtaposed with these opinions, Pasierb's hermeneutics seem very original in terms of interpreting the Jewish heritage as a part of human experience. His poem, inspired by Chagall, puts forward a clear anthropological statement, with which he thinks Chagall would agree. He states that rejecting the ethical elements of human life (God's Commandments, as in the case of the Hebrew people on their way to Kanaan, but also as in the case of any people who turn themselves against the rule "thou shalt not kill") ends with suffering and constant fear (and it would be very hard to blame God or accuse the Absolute of being guilty). His observations on Chagall's Moses make one think about the original sin and its universal consequences rather than about the story of Exodus or about the Jewish experience in history. In this attempt to interpret Chagall as a painter of a universal, all-human fate, and a wise magician who, using his craft, makes his viewers aware of their own condition, Pasierb is different from most Polish poets who would generally tend to interpret the artist's works in the context this or that particular experience.

16 The Maritains worked together on creating a religious enviroment for a circle of their Jewish acquaintences who were on their way to conversion. The way Raïssa Maritain describes Chagall's art proves that she would probably include the painter into this category. Still, the Maritains were very tactful and considerate in relation to Chagall, and probably never suggested to him in a direct manner the possibility of turning towards Christianity openly and officially (Wilson). 


\section{Conclusions}

The importance of Chagall's paintings as a subject of Polish post-war poetry is unquestionable. The poems analyzed here form a distinctive group of texts, in most cases of a noticeable poetical quality (about which the philological translations can unfortunately give only a very weak testimony). For many Polish poets in the years 1950s-1980s, Chagall's works became a memento of a lost cultural diversity, the lost Jewish population living in Poland in the interwar period, and its cultural heritage. Its importance does not lie in its artistic qualities, nor in its formal achievements-which must be mentioned, especially because its image in French poetry is, as I have indicated in the beginning, very different.

Among the many factors which influenced the reception of Chagall in Polish poetry, one can name the lack of possibility (in most cases) of experiencing a personal encounter with the original works. In the decades between 1950 and 1989, the possibility of seeing works of Chagall was even more limited than before the war due to the political situation and the restrictions on travelling from Poland to the countries where the paintings could be experienced. In both cases, the poets were mostly condemned to the mediation of reproductions. The only evident exception is the poetry by Janusz Pasierb, who saw not only Chagall's works in Jerusalem, but also the exhibition Marc Chagall et la Bible in Geneva in 1962, and reviewed it for a Polish weekly Tygodnik Powszechny (cf. Peroń 162).

The examples analyzed prove that Chagall became incorporated into Polish poetry and constitutes a part of the local literary tradition. His paintings supported a collection of meaningful motifs, helping the discussed poets speak on the very painful topic of irretrievable loss, a discussion of which is almost unfeasible with the standard means of expression. The loss of the vast material tradition of the Polish Jewry severed any traces of cultural continuity: not only were the people who created this tradition tragically killed, but also gone were their works and homes, thus depriving future generations the cultural artifacts and which would enable them to maintain their memory (Ficowski's metaphor of "a desert land" seems very suitable here). Hence, there was actually no serious source of inspiration which could compete with Chagall's visual language describing the shtetl, which Polish poets could turn to. What is interesting, they took for granted such qualities of Chagall's paintings as its inner harmony, joy, overwhelming spirit of compassion, qualities which certainly can be justly thought of as rooted in the Chasidic background of the painter (Wilson 20-22).

Making Chagall a part of Polish cultural language (and the examples I have analyzed hopefully suffice to defend my claim that such an incorporation oc- 
curred successfully ${ }^{17}$ ) requires an ethical engagement. The fact that the poets focused almost entirely on the paintings which took up the shtetl as their subject (out of many possibilities) seems the simplest and the clearest declaration. Even if this resulted in an impoverished image of Chagall in Polish post-war poetry, it must be understood (and, perhaps, justified, if any justification for such artistic choices was necessary) as an act of paying a kind of debt of remembrance to the inhabitants of each and every shtetl, who are no longer with us-and of preserving the memory of them, both as a part of the cultural heritage and as an important moral obligation.

After 1989 Chagall's influence on Polish poetry did not stop; on the contrary, its numerous examples inspired Magdalena Rabizo-Birek to devote to them a short critical commentary (Rabizo-Birek). The fact that such a commentary exists holds me back from analyzing here the latest Polish "Chagallic" poems; another reason to stop around 1990 is the (generally) underwhelming quality of the later poetical production, or to say the least, a quality not withstanding a comparison with the poems by Ficowski, Kulmowa or Pasierb. What seems interesting, however, is that, according to Rabizo-Birek, after 1989 Chagall is rarely recalled together with any historical (also Holocaust) motifs. The "historical" way of interplaying with the painter's works, which is crucial for the period under consideration, was abandoned by most poets of the younger generation. There is, however, an interesting exception. In a book Vaterland (Homeland; the author uses a German word as the title, 1997) by Tomasz Różycki there is a poem entitled "Later, in a Different Life" ("Później, w innym życiu”), a lyrical song of almost mystical love between a man and a woman, in which some scenes and creatures from Chagall's paintings are recalled, and in which we read (nota bene the last line of the quotation):

There were no limits; on the wings of angles

The same violin melody appeared on and on, the cats

With human faces and people with the heads of goats danced.

We were everything, every single creature.

These wings lifted us and carried away from the pogroms, the sky

17 Due to space limitations, I have decided to leave out some poems (by Artur Maria Swinarski, Anna Frajlich and Ernest Bryll) also written during the decades discussed here, which might have enriched the argument, although would not have changed the general conclusions. 
Turned over Vitebsk and Paris, the clouds

Fell, and we flew as a streak of soot from the crematorium.

[translation mine] (Rabizo-Birek 181)

Nie było żadnych granic, na anielskich skrzydłach

zjawiała się wciąż ta sama melodia na skrzypce, tańczyły

koty z ludzką twarzą, ludzie o koźlich głowach.

Byliśmy wszystkim, każdym stworzeniem.

Te skrzydła unosiły nas z pogromów, niebo

odwracało się nad Witebskiem i Paryżem, upadały

obłoki, a my płynęliśmy smugą sadzy z krematorium.

The unexpected turn in the atmosphere of the poem proves that in Polish literature Chagall became strongly connected with the Shoah, a surprising fact in itself, explained partially by the imagination of the poets whose works, analyzed above, made an important contribution to the Polish literary tradition and its set of motifs.

According to Rabizo-Birek, much more place is given by younger poets to Chagall's painterly imaginary, his metaphysical reflection, mysticism, and the metaphysical concept of love (Rabizo-Birek 180). It seems that after a few decades of making Chagall an important source of inspiration for historical and social discussions, perhaps a gentle and subtle excuse for them, Polish poets have recently been choosing Chagall in a privatized and intimate version. Perhaps this is just a supposition; the field is open for investigation. Such a change in reception around 1990 (let us say, from "history-oriented" to "intimate") might also be noticed in the case of other great painters and their works, inspiring Central European poetry after the Second World War.

\section{| Works Cited}

Biała, Alina. Literatura i malarstwo. Korespondencja sztuk. Warszawa, Bielsko-

-Biała: Wydawnictwo Szkolne Pwn and Park Edukacja, 2010.

Cisowska, Barbara. "List do Marca Chagalla Stanisława Wiechowicza." Judaica 4 (2012): 1-41. 
Czyżewski, Krzysztof. “'You can't do just like that...' Or Jerzy Ficowski’s Path to Reading the Ashes." Polin 21: 460-468.

Erben, Walter. Marc Chagall. London: Thames and Hudson, 1957.

Ficowski, Jerzy. Goraczka rzeczy. Warszawa: PIw, 2002.

Frankel, Hazel. "Home and the Holocaust in Selected Paintins of Marc Chagall and Yiddish Poems of David Fram." Soundings: An Interdisciplinary Journal 101.4 (2018): 341-359.

Jeffrey, David Lyle. "Meditation and Atonement in the Work of Marc Chagall." Religion and the Arts 16 (2012): 211-230.

Kossewska, Elżbieta, ed. Marc Chagall-Dawid Lazer. Listy. Warszawa: Wydawnictwo Neriton, 2018.

Kulmowa, Joanna. Moja petnia, czyli wiersze lubiane. Warszawa: PIW, 2000.

Maritain, Raïssa. “Chagall, czyli burza zaczarowana.” Trans. Maria Żurowska. Warszawa: Biblioteka "Więzi," 2011.

Młynarski, Wojciech. Od oddechu do oddechu. Warszawa: Prószyński i s-ka, 2017.

Pasierb, Janusz Stanisław. Kategoria przestrzeni. Warszawa: Czytelnik, 1978.

Peroń, Małgorzata. Plastyczna mapa świata. Poezja ks. Janusza S. Pasierba wobec sztuk wizualnych. Lublin: Wydawnictwo KUL, 2015.

Rabizo-Birek, Magdalena. "Inspiracje plastyczne w poezji najnowszej (na przykładzie Marca Chagalla).” Fraza 1 (1999): 175-184.

Stankowska, Agata. “Uczynić aby posłuchać.' Wiedza i wiara w poezji Joanny Kulmowej." Joanna Kulnowa wobec świata literatury. Ed. Urszula Chęcińska. Szczecin: Książnica Pomorska, 1998. 47-60.

Sterna-Wachowiak Sergiusz. "List Marc Chagalla do Jerzego Ficowskiego." Gazeta Malarzy i Poetów 1 (1996): 11.

Szurek, Karolina. “Jak malował Chagall.” Portal Historia Poszukaj. Portal Edukacyjny. https://tinyurl.com/wvd5yudc. Accessed 20 August 2020.

Śliwiak, Tadeusz. Wiersze wybrane. Warszawa: Czytelnik, 1975.

Walther, Ingo F. and Rainer Metzger. Marc Chagall 1887-1985. Malarstwo jako poezja. Trans. Ewa Wanat. Warszawa: Taschen/Eidpresse Polska S.A., 2005.

Wilson, Jonathan. Marc Chagall. Biografia. Trans. J. Skowroński. Warszawa: Wydawnictwo Naukowe PWN, 2011.

Winczakiewicz, Jan, ed. Izreal w poezji polskiej. Antologia. Paryż: Instytut Literacki, 1958.

Wullschlager, Jackie. Chagall. NewYork: Knopf Doubleday Publishing Group, 2008. 


\section{| Abstrakt}

Katarzyna SzewCZyK-HaAke

Dzieła Marca Chagalla w poezji polskiej lat 1950-1989

Artykuł przedstawia zjawisko intensywnej i niezwykle owocnej pod względem artystycznym recepcji twórczości Marca Chagalla w polskiej poezji w okresie od lat pięćdziesiątych do lat osiemdziesiątych xx wieku. Przebiegająca innym rytmem niż zachodząca na gruncie zachodnim (w artykule omawiany jest przykład poezji francuskiej), polska recepcja poetycka dzieł Chagalla naznaczona jest przede wszystkim cieniem wydarzeń drugiej wojny światowej i Holocaustu. W sytuacji zniszczenia podczas wojny kulturowych i materialnych śladów obecności wspólnoty żydowskiej na ziemiach polskich malarstwo Chagalla staje się dla wielu poetów (m.in. Jerzego Ficowskiego, Joanny Kulmowej, Janusza S. Pasierba, Tadeusza Śliwiaka) punktem odniesienia umożliwiającym wysłowienie tej części kultury polskiej, która własnych sposobów ekspresji i istnienia została tragicznie pozbawiona.

Słowa kluczowe: malarstwo Marca Chagalla w poezji polskiej; Shoah w poezji polskiej; literatura a malarstwo; Jerzy Ficowski; Joanna Kulmowa; Janusz S. Pasierb

\section{| Abstract}

Katarzyna SzEWCZYK-HaAke

\section{The Works of Marc Chagall in Polish Poetry (from the 1950s to the 1980s)}

The article presents a profound and artistically very successful phenomenon of the reception of Marc Chagall's works in Polish poetry form the 1950 s to the 1980 os. Different from the reception of Chagall in other "Western" literatures (examples discussed in the article derive from French poetry), the Polish reception is marked first of all by the events of the Second World War and the Holocaust. As during the war almost all material and cultural traces of the Jewish presence in Poland were annihilated, the works of Chagall became a point of reference for many poets (e.g. Jerzy Ficowski, Joanna Kulmowa, Janusz S. Pasierb, Tadeusz Śliwiak), enabling them to express a part of Polish culture which was tragically deprived of its own forms of expression and existence. 
Keywords: paintings of Marc Chagall in Polish poetry, Shoah in Polish poetry, literature and fine arts, Jerzy Ficowski, Joanna Kulmowa, Janusz S. Pasierb

\section{| About the Author}

Katarzyna Szewczyk-Haake: Graduate of Polish Studies (2002), PhD in the field of history of Polish literature (2006). Since 2018 she is a professor at the Adam Mickiewicz University in Poznań. Areas of academic interest include comparative literature (especially in the realm of modern Polish and Scandinavian literature), intertextual relations between literature and fine arts, Kierkegaard's legacy in twentieth-century European literature. Author of many books and scientific articles published in professional journals, e.g. Nowoczesna literatura etyczna. O twórczości Józefa Wittlina i Pära Lagerkvista, 2017 (Modern ethical literature. On the works by Józef Wittlin and Pär Lagerkvist, English translation in print), Kolce Grünewalda. Nie tylko o ekfrazach, 2018 (Grünewald's thorns. Not only on the ekphrasis, Russian translation in print).

E-mail: haaczyk@amu.edu.pl

ORCID: 0000-0002-0160-0353 
